\title{
ANALISIS KINERJA APARAT KELURAHAN DALAM PENYELENGGARAAN PEMERINTAHAN DI KELURAHAN BENGKONG LAUT KECAMATAN BENGKONG KOTA BATAM
}

\author{
Indrawati ${ }^{1}$, Linayati Lestari $^{2}$ \\ 1Program Studi Ilmu Pemerintahan, Fakultas Ilmu Sosial dan Ilmu Politik, Universitas Riau Kepulauan, \\ Indonesia \\ indrawati@gmail.com \\ 2Program Studi Ilmu Pemerintahan, Fakultas Ilmu Sosial dan Ilmu Politik, Universitas Riau Kepulauan, \\ Indonesia \\ linayatilestari@yahoo.com
}

\begin{abstract}
Abstrak
Kelurahan adalah wilayah kerja lurah sebagai perangkat daerah kabupaten di bawah kecamatan yang berada di bawah dan bertanggung jawab kepada camat.Kelurahan mempunyai tugas dan fungsi melaksanakan kewenangan pemerintahan yang dilimpahkan oleh Camat serta melaksanakan tugas pemerintahan lainnya sesuai ketentuan perundangan yang berlaku. Hubungan kerja kecamatan dengan kelurahan bersifat hierarki. Pembentukan kelurahan ditujukan untuk meningkatkan kemampuan penyelenggaraan pemerintahan kelurahan secara berdayaguna, berhasilguna dan pelayanan terhadap masyarakat sesuai dengan tingkat perkembangan dan kemajuan pembangunan. Tujuan dari penelitian ini adalah untuk mengetahui sejauh mana kinerja apparat pemerintahan di Kelurahan Bengkong Laut Kecamatan Bengkong Kota Batam. Sedangkan manfaat dari penelitian ini dalam bentuk skripsi diharapkan dapat dipergunakan untuk memenuhi syarat memperoleh gelar Sarjana Ilmu Pemerintahan pada Fakultas Ilmu Sosial dan Ilmu Politik Program Ilmu Pemerintahan Universitas Riau Kepulauan. Dalam penelitian ini, penulis menggunakan Metode Deskriptif Kualitatif untuk melihat bagaimana kinerja aparat Pemerintah Kelurahan terhadap penyelenggaraan pemerintahan di Kelurahan Bengkong Laut Kecamatan Bengkong Kota Batam. Adapun Penelitian ini dilakukan di Kelurahan Bengkong Laut Kecamatan Bengkong Kota Batam, teknik pengumpulan data yang digunakan dalam penelitian ini adalah Observasi Partisipatif (Participant Observatioan) melalui Wawancara dan responden melalui Kuesioner. Hasil yang didapat dalam penelitian ini adalah melalui lima indikator atau variabel yang penulis gunakan didalam penelitian ini yaitu Produktifitas kerja, Tanggung Jawab, Disiplin, Kemampuan Sumber Daya, dan Motivasi, yang sangat berpengaruh didalam kinerja aparat Pemerintah Kelurahan terhadap penyelenggaraan pemerintahan di Kelurahan Bengkong Laut Kecamatan Bengkong Kota Batam tersebut adalah variabel Kemampuan sumber daya manusia, karena dengan Kemampuan sumber daya manusia yang telah di miliki oleh aparat Kelurahan Bengkong Laut tersebut, maka penyelenggaraan roda pemerintahan di Kelurahan Bengkong Laut bisa berjalan dengan baik.

Kata Kunci: Kinerja, Aparat Kelurahan, Penyelenggara Pemerintahan
\end{abstract}

\begin{abstract}
Urban village headman is the work area as the district under district that is under and is responsible to camat. Kelurahan has the duty and function exercise powers delegated by the Head of government and other governments carry out tasks in accordance with applicable laws. The working relationship with administrative districts hierarchical. Establishment of village is aimed to improve the ability of governance villages fruitfully, effecfive and service to the public in accordance with the level of development and progress of the construction. The purpose of this study was to determine the extent to which the performance of government officials in the Village of Sea Bengkong Bengkong District of Batam. While the benefits of this research in the form of the thesis is expected to be used to qualify for a Bachelor's degree in Public Administration at the Faculty of Social and Political Science Public Administration Program, University of Riau Islands. In this study, the authors used qualitative
\end{abstract}


descriptive method to see how the performance of government officials to the village of governance in Sub Sea Bengkong Bengkong District of Batam. The research was conducted in the village Bengkong Bengkong districts northwest of Batam, data collection techniques used in this study is a Participant Observation (Participant Observatioan) through interviewsand respondence through kuesioner. The results obtained in this study is five indicators or variables that I use in this study, namely productivity of labor, Responsibility, Discipline, Capability Human Resources, and Motivation, which is very influential in the performance of government officials Village on governance in Sub Bengkong Sea Subdistrict Bengkong Batam City is variable ability of human resources, due to the ability of human resources has been owned by the sea Bengkong village officials, the administration of the wheels of government in the village Bengkong sea can run well.

Keywords : Performance, Village Apparatus, Governance Village.

\section{PENDAHULUAN}

Berdasarkan Undang-undang Dasar Republik Indonesia 1945, negara Indonesia adalah Negara Kesatuan yang berbentuk Republik. Sesuai ketentuan pasal 4 ayat (1) UUD 1945, dalam penyelenggaraan pemerintahan dinyatakan bahwa Presiden Republik Indonesia memegang kekuasaan pemerintahan1. Mengingat wilayah Indonesia yang sangat luas, UUD 1945 beserta perubahannyan telah memberikan landasan konstitusional mengenai penyelenggaraan pemerintahan daerah di Indonesia. Di antara ketentuan tersebut yaitu: pertama, prinsip pengakuan dan penghormatan negara terhadap kesatuan-kesatuan masyarakat hukum adat serta hak-hak tradisionalnya sepanjang masih hidup dan sesuai dengan perkembangan masyarakat dan prinsip Negara Kesatuan Republik Indonesia; kedua, Prinsip daerah mengatur dan mengurus sendiri urusan pemerintahan menurut asas otonomi dan tugas pembantuan; ketiga, prinsip menjalankan otonomi seluas-luasnya; keempat, prinsip mengakui dan menghormati pemerintahan daerah yang bersifat khusus dan istimewa.

Kebijakan otonomi daerah dalam UU Nomor 32 tahun 2004 dijelaskan bahwa pemerintah daerah diberikan kewenangan yang luas, nyata, bertanggung jawab kepada daerahnya, sehingga memberikan peluang kepada daerah agar leluasa mengatur dan melaksanakan kewenangannya atas prakarsa sendiri sesuai dengan kepentingan masyarakat setempat dan potensi setiap daerah.

Seiring diimplementasikan Undang-undang nomor 53 Tahun 1999 sebagaimana telah diubah dengan Undang-undang nomor 13 Tahun 2000 tentang Perubahan atas Undangundang Nomor 53 tahun 1999 tentang Pembentukan Kota Batam yang semula sebagai Kota Administratif Batam statusnya berubah menjadi Daerah Otonom Kota Batam. Untuk itu dalam struktur pemerintahan dan penataan wilayahnya juga mengalami perubahan. Berdasarkan Peraturan Daerah Nomor 2 Tahun 2005 tentang Pemekaran, Perubahan dan 
Pembentukan Kecamatan dan Kelurahan dalam Daerah Kota Batam dinyatakan bahwa semula terdiri dari 8 Kecamatan dan 51 Kelurahan berubah menjadi 12 Kecamatan dan 64 Kelurahan.

Konsekuensi dari hal tersebut pemerintah kelurahan dituntut memiliki kemampuan yang semakin tinggi untuk menjawab tantangan tugas yang semakin berat. Karena itu, diperlukan upaya untuk meningkatkan kemampuan pemerintah kelurahan baik kemampuan dalam mengambil inisiatif, prakarsa, perencanaan, pelaksanaan maupun pengawasan, sehingga diperoleh kinerja pemerintah yang baik.

Kelurahan adalah wilayah kerja lurah sebagai perangkat daerah kabupaten di bawah kecamatan yang berada di bawah dan bertanggung jawab kepada camat. Kelurahan mempunyai tugas dan fungsi melaksanakan kewenangan pemerintahan yang dilimpahkan oleh Camat serta melaksanakan tugas pemerintahan lainnya sesuai ketentuan perundangan yang berlaku. Hubungan kerja kecamatan dengan kelurahan bersifat hierarki. Pembentukan kelurahan ditujukan untuk meningkatkan kemampuan penyelenggaraan pemerintahan kelurahan secara berdayaguna, berhasilguna dan pelayanan terhadap masyarakat sesuai dengan tingkat perkembangan dan kemajuan pembangunan.

Efisiensi dalam memberikan pelayanan selain disebabkan oleh jumlah apparat yang tidak seimbang dengan jumlah penduduk yang harus dilayani, juga disebabkan oleh banyaknya jenis pelayanan yang diberikan kelurahan kepada masyarakat. Kinerja secara umum dapat dipahami sebagai besarnya kontribusi yang diberikan pegawai terhadap kemajuan dan perkembangan di lembaga tempat dia bekerja. Dengan demikian diperlukan kinerja yang lebih intensif dan optimal dari bagian organisasi demi optimalisasi bidang tugas yang di embannya. Kinerja suatu organisasi sangat penting, oleh karena dengan adanya kinerja maka tingkat pencapaian hasil akan terlihat sehingga akan dapat diketahui seberapa jauh pula tugas yang telah dipikul melalui tugas dan wewenang yang diberikan dapat dilaksanakan secara nyata dan maksimal. Kinerja organisasi yang telah dilaksanakan dengan tingkat pencapaian tertentu tersebut seharusnya sesuai dengan misi yang telah ditetapkan sebagai landasan untuk melakukan tugas yang diemban. Dengan demikian kinerja (performance) merupakan tingkat pencapaian hasil atau the degrees of accomplishment. 
Tabel 1 Prestasi Kelurahan Bengkong Laut (2011-2014)

\begin{tabular}{|c|l|}
\hline Tahun & \multicolumn{1}{|c|}{ Prestasi } \\
\hline 2011 & $\begin{array}{l}\text { Juara Harapan 1 Perpustakaan terbaik desa/kelurahan Propinsi } \\
\text { Kepulauan Riau 2011 }\end{array}$ \\
\hline 2012 & Juara 3 Lomba Kelurahan tingkat kota Batam 2012 \\
\hline 2013 & Juara 3 Lomba Kelurahan tingkat kota Batam 2013 \\
\hline 2014 & Juara Umum MTQ tingkat Kecamatan Bengkong 2014 \\
\hline
\end{tabular}

Sumber: Kantor Kelurahan Bengkong Laut

Dalam rangka membangun kualitas kinerja pemerintahan yang efektif dan efisien, diperlukan waktu untuk memikirkan bagaimana mencapai kesatuan kerjasama sehingga mampu meningkatkan kepercayaan masyarakat. Untuk itu, diperlukan otonomi serta kebebasan dalam mengambil keputusan mengalokasikan sumber daya, membuat pedoman pelayanan, anggaran, tujuan, serta target kinerja yang jelas dan terukur. Kelurahan sebagai organisasi pemerintahan yang paling dekat dan berhubungan langsung dengan masyarakat merupakan ujung tombak keberhasilan pembangunan kota khususnya otonomi daerah, dimana kelurahan akan terlibat langsung dalam perencanaan dan pengembalian pembangunan serta pelayanan.

Dikatakan sebagai ujung tombak karena kelurahan berhadapan langsung dengan masyarakat, oleh karena itu kelurahan harus mampu menjadi tempat bagi masyarakat untuk diselesaikan atau meneruskan aspirasi dan keinginan tersebut kepada pihak yang berkompeten untuk ditindak lanjuti. Disamping itu peran kelurahan di atas menjembatani program-program pemerintah untuk disosialisasikan kepada masyarakat sehingga dapat dipahami dan didukung oleh masyarakat. Adapun yang berpengaruh dengan permasalahan tersebut adalah dalam hal pemberian kesempatan meningkatkan kemampuan dan pemberian wewenang secara proporsional sehingga dapat menentukan baik-buruknya kinerja pemerintah kelurahan. Karena itu, kinerja aparat membutuhkan kemampuan dan motivasi baik dalam pencapaian hasil pelaksanaan tugas maupun dalam usaha pemberian layanan yang berkualitas kepada masyarakat. 


\section{Kinerja, Aparat Kelurahan, dan Penyelenggara Pemerintahan}

Istilah kinerja berasal dari kata job performance atau actual performance (prestasi kerja atau prestasi sesungguhnya yang dicapai seseorang). Kinerja adalah hasil kerja seorang pegawai selama periode tertentu dibandingkan dengan berbagai kemungkinan, misalnya standar target, sasaran, atau kriteria yang telah ditentukan terlebih dahulu dan disepakati bersama. Jika pegawai tidak melakukan pekerjaannya, maka suatu organisasi akan mengalami kegagalan. Aparat kelurahan adalah orang atau pegawai yang bertugas menjaga kelancaran administrasi dan pelayanan di kantor lurah; sementara Penyelenggaraan pemerintahan meliputi, tata cara penunjukan pejabat, penentuan kebijakan, pertanggungjawaban, pengawasan dan lain-lain.

Dalam melaksanakan kinerja, pihak pemerintah kelurahan harus terlebih dahulu melihat semua faktor kemungkinan yang ada, baik itu kesempatan, peluang maupun tantangan serta hambatan apa yang ada dalam era otonomi ini serta penyelenggaraan pemerintahan haruslah pula menjawab serta memenuhi kehendak pelanggan yaitu masyarakat di kelurahan yang memerlukan pelayanan secara optimal agar tercipta suatu keadaan yang menggambarkan good governance di Kelurahan Bengkong Laut. Jenis-jenis pelayanan yang diberikan aparat kelurahan kepada masyarakat antara lain dapat dilihat pada table 1.2 dibawah ini:

Tabel 2 Jenis-Jenis Pelayanan yang Diberikan Kelurahan kepada Masyarakat

\begin{tabular}{|c|c|}
\hline No & Jenis Pelayanan \\
\hline 1. & Pelayanan Pembuatan KTP dan KK \\
\hline 2. & Pengantar Pembuatan Surat Keterangan \\
\hline 3. & Pengantar Pembuatan SKCK \\
\hline 4. & Kependudukan (Nikah, Cerai, Lahir, Mati) \\
\hline \multicolumn{2}{|c|}{ Sumber: Kantor Kelurahan Bengkong Laut } \\
\hline
\end{tabular}

\section{METODELOGI}

\section{Jenis Penelitian}

Jenis penelitian yang digunakan dalam penelitian ini adalah metode analitis kualitatif yaitu suatu metode yang menggambarkan suatu gejala yang ada pada waktu penelitian dengan jalan mencari dan mengumpulkan data sebanyak-banyaknya yang diperoleh dari lapangan, yang kemudian secara sistematis dan analisa sesuai dengan teori yang ada. 


\section{Lokasi Penelitian}

Penelitian dilakukan di Kantor Lurah Kelurahan Bengkong Laut Kecamatan Bengkong Kota Batam Tahun 2014-2015 beralamat Jl. Bengkong Laut No 01 Kode Pos 29457.

\section{Sumber Data}

Yaitu data yang diperoleh langsung dari sumber pertama berupa pengamatan atau observasi secara langsung yang didukung oleh wawancara terhadap informan atau pihakpihak yang bersangkutan. Data yang diperlukan dalam penelitian ini meliputi: a). Data Primer, yakni data yang diperoleh langsung melalui penelitian lapangan (wawancara) dan responden melalui kuesioner; dan b). Data Sekunder, yakni data yang diperoleh diperoleh dari dokumen-dokumen resmi, buku-buku, hasil-hasil penelitian yang berwujud laporan, dan sebagainya.

\section{Populasi dan Sampel}

Pada penelitian ini yang disebut populasi adalah Staf Bengkong Laut, Rukun Warga yang berjumlah 11 RW, Rukun Tetangga yang berjumlah 49 RT, dan Penduduk Bengkong Laut yang berjumlah lebih kurang 14.315 jiwa. Teknik pengambilan sampel dalam penelitian ini adalah secara purposive random sampling.Purposive random sampling adalah penentuan sampel dengan pertimbangan tertentu. Pada penelitian ini dari populasi yang berjumlah 14.315 jiwa, sampel yang digunakan sebanyak 33 jiwa. Dengan sampel sejumlah itu diharapkan sudah memenuhi persyaratan dalam pengambilan sampel

\section{PEMBAHASAN}

Dari hasil kuesioner penelitian yang penulis lakukan dengan menggunakan tiga indikator penelitian yaitu Produktivitas kerja, Tanggung Jawab, Disiplin,. Dari ketiga indikator tersebut penulis menganalisa hasil penelitian tersebut yang penulis simpulkan melalui rekapitulasi tabel berikut: 
Tabel 3 Hasil Rekapitulasi kinerja aparat Pemerintah Kelurahan terhadap penyelenggaraan pemerintahan di Kelurahan Bengkong Laut Kecamatan Bengkong Kota Batam

\begin{tabular}{|c|c|c|c|}
\hline No. & Indikator & Tanggapan Responden & Persentase \\
\hline \multirow[t]{3}{*}{1} & \multirow[t]{3}{*}{ Sikap Aparatur } & Ramah & 30,30 \\
\hline & & Cukup ramah & 57,57 \\
\hline & & Kurang ramah & 15,16 \\
\hline \multirow[t]{3}{*}{2} & \multirow[t]{3}{*}{ Kemampuan } & Cepat & 51,51 \\
\hline & & Cukup cepat & 36,36 \\
\hline & & Kurang cepat & 12,13 \\
\hline \multirow[t]{3}{*}{3} & \multirow[t]{3}{*}{ Penyelenggaraan } & Sangat baik & 51,51 \\
\hline & & Baik & 36,36 \\
\hline & & Tidak baik & 12,13 \\
\hline \multirow[t]{3}{*}{4} & \multirow[t]{3}{*}{ Tanggung jawab } & Sangat bertanggung jawab & 51,51 \\
\hline & & Bertanggung jawab & 33,34 \\
\hline & & Tidak bertanggung jawab & 15,15 \\
\hline \multirow[t]{3}{*}{5} & \multirow[t]{3}{*}{ Kedisiplinan } & Sangat disiplin & 15,15 \\
\hline & & Disiplin & 48,49 \\
\hline & & Tidak disiplin & 36,36 \\
\hline \multirow[t]{3}{*}{6} & \multirow[t]{3}{*}{ Hadir secara rutin } & Sudah sangat rutin & 18,18 \\
\hline & & Rutin & 45,46 \\
\hline & & Tidak hadir secara rutin & 36,36 \\
\hline \multirow[t]{3}{*}{7} & \multirow[t]{3}{*}{ Hadir tepat waktu } & Sangat tepat waktu & 9,09 \\
\hline & & Tepat waktu & 39,40 \\
\hline & & Tidak tepat waktu & 51,51 \\
\hline \multirow[t]{3}{*}{8} & \multirow[t]{3}{*}{ Kinerja } & Sudah optimal & 48,48 \\
\hline & & Optimal & 33,33 \\
\hline & & Tidak optimal & 18,19 \\
\hline
\end{tabular}

Sumber: Diolah Peneliti

Mengenai analisis kinerja aparat Kelurahan Bengkong Laut di dalam menyelenggarakan roda pemerintahan yang diukur melalui hasil kerja aparat Kelurahan Bengkong Laut tersebut.Penulis menganalisa penelitian ini dengan melakukan wawancara mendalam kepada Lurah Bengkong Laut yaitu Bapak Wendhy S. Pratama, S.STP sebagai berikut:

"Mengenai kinerja aparat kelurahan itu memiliki prilaku yang beragam, tergantung dari tanggung jawab dari masing-masing individu. Sebenarnya dari kinerjanya sudah baik, namun harus bisa lebih di optimalkan lagi. Semua itu kembali ke individu masing-masing56". 
Dari hasil wawancara tersebut penulis bisa menganalisa bahwa kinerja aparat Kelurahan Bengkong Laut dalam penyelenggaraan roda pemerintahan sudah di katakan baik, namun harus bisa lebih ditingkatkan lagi untuk memperoleh hasil yang optimal. Namun semua itu kembali pada tanggung jawab dari masing-masing individu aparat kelurahan yang memiliki perilaku dan sikap yang beragam.

\section{KESIMPULAN}

Kelurahan adalah wilayah kerja lurah sebagai perangkat daerah kabupaten di bawah kecamatan yang berada di bawah dan bertanggung jawab kepada camat. Kelurahan mempunyai tugas dan fungsi melaksanakan kewenangan pemerintahan yang dilimpahkan oleh Camat serta melaksanakan tugas pemerintahan lainnya sesuai ketentuan perundangan yang berlaku. Hubungan kerja kecamatan dengan kelurahan bersifat hierarki. Pembentukan kelurahan ditujukan untuk meningkatkan kemampuan penyelenggaraan pemerintahan kelurahan secara berdayaguna, berhasil guna dan pelayanan terhadap masyarakat sesuai dengan tingkat perkembangan dan kemajuan pembangunan. Berdasarkan uraian dan pembahasan yang dikemukakan penulis dalam bab-bab sebelumnya, dapat ditarik kesimpulan sebagai berikut: Pertama, Produktifitas Kerja, produktivitas kerja aparat Kelurahan Bengkong Laut sudah optimal, namun perlu lebih di tekankan lagi ke arah kemampuan, pengetahuan, kualitas sumber daya manusianya dalam penyelenggaraan roda pemerintahan di Kelurahan Bengkong Laut; Kedua, Tanggung Jawab, tanggung jawab sangat penting di dalam mewujudkan kinerja yang baik, khususnya mengenai penyelenggaraan pemerintahan di kelurahan Bengkong Laut Kecamatan Bengkong.

Ketiga, Disiplin, masih terdapatnya pelanggaran yang mengenai kedisiplinan waktu kerja di Kelurahan Bengkong Laut. Hal ini memicu pada pola pelayanan dan penyelanggaraan pemerintahan yang belum baik. Namun untuk kedepannya akan di terapkan sistem absen sidik jari yang akan memudahkan pengontrolan disiplin waktu oleh atasan langsung; Keempat, Kemampuan Sumber Daya, bahwa penempatan sumber daya di Kelurahan Bengkong Laut sudah tepat dan sesuai dengan kemampuan yang di miliki dari masing-masing aparat kelurahan, namun semua kembali pada tugas dan tanggung jawab dari masing-masing individu sesuai dengan standar operasional yang telah berlaku. Bisa juga di katakan walaupun standar operasional prosedur sudah jelas dan telah di transformasikan 
dengan tepat, namun pelaksanaan kebijakan tersebut tidak akan berjalan efektif jika tidak didukung dengan sumberdaya manusia yang berkualitas, yang memiliki keterampilan, serta mengetahui tugas pokok dan fungsinya.

Kelima, Motivasi, motivasi sangat berpengaruh besar didalam penyelenggaraan roda pemerintahan di Kelurahan Bengkong Laut. Motivasi yang dimaksud terletak pada segi peningkatan kesejahteraan aparat, misalnya melalui tunjangan gaji yang di nilai dari pencapaian kinerja aparat, itu sangat menjadi faktor yang paling berpengaruh didalam keberhasilan penyelenggaraan roda pemerintahan di kelurahan bengkong laut. Selain itu motivasi eksternal juga menjadi kekuatan yang ada di dalam individu yang dipengaruhi oleh faktor internal yang dikendalikan oleh pimpinan, yaitu meliputi penghargaan, kenaikan pangkat dan tanggung jawab. Motivasi eksternal meliputi faktor pengendalian oleh pimpinan kelurahan yang meliputi hal-hal yang berkaitan dengan pekerjaan seperti halnya gaji atau upah, keadaan kerja dan kebijaksanaan kelurahan dan pekerjaan yang mengandung hal-hal seperti penghargaan, pengembangan dan tanggung jawab. Lurah yang sebagai perlu mengenai motivasi eksternal untuk mendapatkan tanggapan yang positif dari apparat kelurahan. Tanggapan yang positif ini menunjukkan bahwa bawahan sedang bekerja demi keberhasilan penyelenggaraan roda pemerintahan di Kelurahan Bengkong Laut. Pimpinan kelurahan dapat menggunakan motivasi eksternal yang positif maupun negatif. Motivasi positif merupakan penghargaan atas prestasi yang sesuai, sedangkan motivasi negatif mengenakan sanksi jika prestasi tidak dapat dicapai.

\section{DAFTAR PUSTAKA}

Amiruddin. (2004). Pengantar Metode Penelitian Hukum. Jakarta: Raja Grafindo Persada Azwar, Saifuddin. (2014). Metode Penelitian. Yogyakarta: Pustaka Belajar Bungin, Burhan. (2005). Metodologi Penelitian Kuantitatif. Jakarta: Kencana Hasibuan, Malayu S.P. (2002). Manajemen Sumber Daya Manusia. Jakarta: Bumi Aksara John M. Ivancevich. (2002). Perilaku dan Manajemen Organisasi. Bandung: Erlangga Kartini Kartono. (2000). Pengantar Metodologi. Bandung: Research Sosial Alumni Mahsun, Mohamad. (2006). Pengukuran Kinerja Sektor Publik. Yogyakarta: BPFE 
Moeheriono. (2010). Pengukuran Kinerja Berbasis Kompetensi Edisi Revisi. Jakarta: PT. Raja Grafindo Persada

Keban, Yeremias. (2004). Enam Dimensi Strategis Administrasi Publik Konsep Teori Dan Isu. Yogyakarta : Gava Media

Rawirosentono. (1999). Bahasa Komprehensif Strategi Pengambilan Keputusan. Jakarta: Bumi Aksara

Sedarmayanti. (2011). Membangun dan Mengembang Kepemimpinan Serta Meningkatkan Kinerja Untuk Meraih Keberhasilan. Bandung: Refika Aditama

Sobandi. (2006). Organisasi menurut Input, Output, Outcome, Benefit. Yogyakarta: Gramedia.

Sugiyono. (2005). Memahami Penelitian Kualitatif. Bandung: Afabeta Metode Penelitian Kuantitatif, Kualitatif, Dan R \& D. Bandung: Alfabeta

Suharsimi Arikunto. (1998). Prosedur Penelitian Suatu Pendekatan Praktek, Jakarta: Rineka Kepu Cipta

Syuhandhak, Mokhamad. (1994). Administrasi Kepagawaian Negara,Teori dan Praktek Penyelenggaraannya di Indonesia. Jakarta: Toko Gunung Agung

Widodo, Joko. (2005). Membangun Birokrasi Berbasis Kinerja, Malang: Bayumedia Publishing

Undang - Undang Dasar1945 dan Perubahannya, Jakarta: Puspaswara. 2008

Undang-undang Nomor 12 tahun 2008 pasal 1 butir n, Tentang Otonomi Daerah

Peraturan Walikota Batam No 29-I Tahun 2010 tentang Uraian Tugas Pokok dan Fungsi Kecamatan dan Kelurahan Kota Batam

Profil Kota Batam Tahun 2014

Profil Kecamatan Bengkong Kota Batam Tahun 2014

Profil Kelurahan Bengkong Laut Kecamatan Bengkong Kota Batam Tahun 2014 